Cahiers $d u$ MONDE RUSSE

\section{Cahiers du monde russe}

Russie - Empire russe - Union soviétique et États indépendants

44/2-3 | 2003

Les pratiques administratives en Union soviétique, 1920-1960

\title{
Rebuilding the Soviet nomenklatura 1945-1948
}

\section{Moshe LEWIN}

\section{(2) OpenEdition}

Journals

Édition électronique

URL : https://journals.openedition.org/monderusse/8608

DOI : $10.4000 /$ monderusse. 8608

ISSN : $1777-5388$

Éditeur

Éditions de l'EHESS

Édition imprimée

Date de publication : 1 avril 2003

Pagination : 219-252

ISBN : 2-7132-1813-6

ISSN : $1252-6576$

Référence électronique

Moshe LEWIN, «Rebuilding the Soviet nomenklatura 1945-1948 », Cahiers du monde russe [En ligne], 44/2-3 | 2003, mis en ligne le 01 janvier 2007, consulté le 02 septembre 2022. URL : http://

journals.openedition.org/monderusse/8608; DOI : https://doi.org/10.4000/monderusse.8608 


\section{CAIR N}

chercher : repérer : avancer

Cet article est disponible en ligne à l'adresse :

http://www.cairn.info/article.php?ID REVUE=CMR\&ID NUMPUBLIE=CMR 442\&ID ARTICLE=CMR 4420219

Rebuilding the Soviet nomenklatura 1945-1948

par Moshe LEWIN

| Editions de l'EHESS | Cahiers du monde russe

2003/2-3 Vol 44

ISSN 1252-6576 | ISBN 2713218136 | pages 219 à 252

Pour citer cet article :

- LEWIN M., Rebuilding the Soviet nomenklatura 1945-1948, Cahiers du monde russe 2003/2, Vol 44, p. $219-252$.

Distribution électronique Cairn pour les Editions de l'EHESS.

(C) Editions de l'EHESS. Tous droits réservés pour tous pays.

La reproduction ou représentation de cet article, notamment par photocopie, n'est autorisée que dans les limites des conditions générales d'utilisation du site ou, le cas échéant, des conditions générales de la licence souscrite par votre établissement. Toute autre reproduction ou représentation, en tout ou partie, sous quelque forme et de quelque manière que ce soit, est interdite sauf accord préalable et écrit de l'éditeur, en dehors des cas prévus par la législation en vigueur en France. Il est précisé que son stockage dans une base de données est également interdit. 


\section{REBUILDING THE SOVIET NOMENKLATURA 1945-1948}

The term "nomenklatura" became popular in Soviet studies in the early 1980s and it was used to denote both the set of procedures the ruling party developed to conduct its staffing policies, and the cohort itself of officials who, having been selected through these procedures, coalesced into the Soviet Union's "ruling class." Before proceeding any further, it is worth pointing out the curious fact that earlier, often very reputable, histories of the Soviet political system did not even use this term, although the discovery of "nomenklatura" implied that it revealed something new and that earlier writers might have missed something important. An implication like that would be inaccurate. Earlier authors often departed from the common knowledge that the ruling party, in fact and by its own admission, had appointed its own members to the most important positions in the state's administration and in the party's own apparatus, since the early stages of the regime. And it was done by a well-known party apparatus department - the Uchraspred. The precise staffing procedures of the country's institutions could await further more detailed monographs. Despite the impression of some new revelation, a new key to Soviet reality, the authors who put such a great emphasis on "the nomenklatura" and "its power" did in fact tell the same story, sometimes even less competently than others. Introducing a new, catchy term meant just this - a term.

On the other hand, the classifier "ruling class" that intended to reveal the socio-political content of the "Soviet nomenklatura" was potentially a more interesting idea - had it not been for the fact that it was used, primarily, as an ideological teaser. "Ruling classes," it seems, is not the term writers like Milovan Djilas or Michael Voslensky would use to tease other countries - but they were ready to use it for the USSR in order to beat it at its own game, using Marxist vocabulary to imply that the USSR had a class structure and a "ruling class." But the play with these terms did not improve matters for us either. All this was said by - and maybe taken from - say, a Soviet oppositionist like Christian Rakovsky, who analyzed the making of a Soviet ruling stratum in texts from 1928 
and 1931 but used "ruling stratum" or "elite", not "class" - the latter having been a contentious term among party oppositionists of the 1920s, notably because it was quite problematic to speak then of the Soviet leadership and of its apparaty as being owners of production means as was the case with feudal lords or capitalist entrepreneurs. ${ }^{1}$

"Nomenklatura" proponents might have had a point had they explained what was gained by the new emphasis on "ruling class" instead of some other concept. An elite is a narrower, less ramified social group than a "class." A class may contain one or more elites but it also needs a rather large social base of its own and supportive groups inside society. If better defined and shown as evolving over time, the definition and study of such social constructs could have deepened our understanding of the evolution, vitality or decline of the system, because the development, especially after Stalin, made the use of a sui generis "ruling class" justified at some stage. With a further proviso that the role of the different meanings and practices related to the term "nomenklatura" needs explaining and should not be used as just some catchy novelty.

Be that as it may, we are mentioning the "class" versus "elite" (or "stratum") quandary just in passing. Our main focus here for the moment is the actual technique of the "nomenklatura" as one of the party's devices to maintain its control. It is sometimes claimed, notably these days in Russia, that the "nomenklatura" system was the ultimate arcanum imperii of the regime. We will show why dealing with "the technique" is of interest, but will also insist that handling the staffing of leading positions in party and state apparaty can be understood only as part of a broader ongoing process of the bureaucratic takeover of all the levers of power, whereby the administrative upper layers - the main object of the party's control - turned into an encrusted power grid.

If so, "nomenklatura" in itself was no key to the system. Actually, there was no single key to this gate although many just craved for one - a bundle of keys is necessary. Bureaucracy was not just being there - it was evolving, exhibiting trends and undergoing changes. The ruling networks were "mutating" - and so was the society around them. No particular technique gives a sufficient account of the complexity of the phenomenon. Our study does focus on the "technique" and cannot do much more - but the correlations with broader systemic trends will be strongly suggested as crucial for the analysis of the stages the system went through and of its demise. Otherwise, the outlandishly sounding term "nomenklatura" remains just a scarecrow.

We are concentrating on the1945-1948 period, notably because good archival material became available but also because this was an important postwar period when the system, including the party machinery, had to be rebuilt, thereby unraveling also many phenomena the party was facing and was going to face till the

1. Milovan Djilas, The new class: an analysis of the Communist system (New York, 1957); M. Voslensky, Nomenklatura: the Soviet ruling class (preface by M. Djilas) (Garden City, NY: Doubleday, 1984). 
end of its existence. ${ }^{2}$ Occasional glimpses into later years will also be offered to make these implications clearer. But first, a thumbnail sketch should be offered of the making of policies that can be grouped under the "nomenklatura" label.

\section{The cadres' policy: delving into the apparatus of the Central Committee}

Party and state organizations must be staffed - and the party took this function upon itself from the very beginning, for the party's own cadres in the first place. Quite soon though, all the key positions of power and influence in the state were included in what became an intricate procedure being worked and reworked as the system passed through ever more complicated stages.

"Nomenklatura" meant, at first, a list of key jobs in party and state administrations to be filled by politically reliable and professionally competent personnel. But the term came to be used to denote the whole, ever more complicated set of procedures of selecting personnel for jobs of responsibility, from the highest to the lowest in all the administrations. A special department in the party apparatus - changing its name and structure over time - dealt with this task. It worked at establishing lists by branch, rank and category, and fixing the level of party or state body (Politbiuro (PB), Orgbiuro, TsK Secretariat, Sovmin or ministries themselves) - obviously depending on the ranks to be filled - to whom names of candidates for office were to be submitted for final approval (or rejection). The practice was actually begotten initially by the dearth of leading party personnel during the civil war. It made the early administrative bodies of the party's Central Committee - the Organizational bureau, the Secretariat and an "Uchraspred" (Uchetno-raspredelitel'nyi otdel: Registration and Distribution Department) - indispensable and overworked. Thus a very much needed candidate for party secretaryship in a locality - who had to be elected according to the party's statute - was sent in from above and quite predictably, immediately elected. The habit stayed on - the proverbial Il n'y a que le provisoire qui dure proved to be valid yet again: the practice of election of top officials by the membership of local organizations began to wither away initially, in fact, unwittingly.

The slogan (and practice) declaring that "Cadres are the key" (Kadry reshaiut vse) for making a revolutionary policy work, also emerged out of the same experience of the early upheavals in the regime's history. The dearth of cadres actually meant dependence of the regime on the availability of energetic and dedicated leaders who could rally existing supporters or administer political institutions that could stabilize the new regime's inherently shifty and fragile

2. Archival sources for this paper were found in the State Archive of the National Economy (Rossiiskii gosudarstvennyi arkhiv ekonomiki - RGAE), in the State Archive of the Russian Federation (Gosudarstvennyi arkhiv Rossiiskoi Federatsii - GARF) and in the Russian Center for the Preservation and Study of Documents in Modern History (RTsKhIDNI now renamed RGASPI - Rossiiskii gosudarstvennyi arkhiv sotsial'no-politicheskoi istorii). It is not as yet always possible to publish precise references to the documents used. 
foundations. In the longer run, the system's evolution (into Stalinism) turned the dependence on cadres into a source of political paranoia and a wish to escape this liability by periodically turning them into scape goats. Before this aspect actually becomes visible, we are allowed to argue that Stalin's slogans concerning the role of "cadres" contained the seeds not just of his future paranoia, but actually of the very essence of Stalin's rule. All this can be gleaned from Stalin's own presentation of the problem as he revealed it to the XII Party Congress and put it firmly on the party's agenda.

Stalin wanted cadres to be "people who know how to execute directives, understand them, accept them as their very own and who know how to transform them into reality. Otherwise, politics loses its meaning, it turns into ineffectual waving of one's arms. This is why Uchraspred becomes so enormously important. [...] it is indispensable to study every nominee in minute detail." 3

It is easy to see how a conception like that, if and when it gets actually adopted, would put an end to the existence of the party as a sovereign political body. Cadres were here to carry out orders - quite obviously not to participate in choosing the policies to be executed. Anyone in the party actually belonging to "cadres," the party continued to merit the designation "political" so long as oppositions could still do battle for alternative strategies. Moreover, what is important for our theme here is the not clear implication of Stalin's pronouncements on "cadres" that the quality of policies and strategies decreed from above could never be wrong. Everything depended entirely on the quality of the executors. The idea of purges as retribution for failure by cadres to deliver the expected results was inscribed in such a conception and it remained valid for the whole Stalinist period.

\section{The nomenklatura before 1946}

Our sketch of the early stages of the policy borrows details from an article by two Russian authors, who alternate some judicious statements and an attempt at a broad sociological analysis with unwarranted hyperboles about the nomenklatura. ${ }^{4}$ They see it as a "uniform system," "military in its harshness," involving several million people. Their data do not support this kind of generalization and we will see that things actually looked rather differently.

The names of the departments that had been dealing with cadres since the inception of the policy kept changing: it could be "Orginstr" and/or "Uchraspred" or, as of 1923, "Orgraspred" - acronyms pertaining in each case to organization, registration and distribution of personnel.

It was the XII Party Congress (April 1923) that called on the Central Committee to select not just party leaders but also soviet, economic, cooperative and other

3. Stalin's speech, XII S“ezd VKP(b), stenograficheskii otchet (Moscow, 1923): 57.

4. T. P. Korzhikhina, Iu. Iu. Figatner, "Sovetskaia nomenklatura: stanovlenie, mekhanizmy deistviia," Voprosy istorii, 7 (1993): 25-38. 
leading personnel. The Uchraspred department had to be strengthened to cope with the task and in mid-1923, a commission under Molotov and Kaganovich prepared the resolution "on nominations" that the CC endorsed and the XIII Party Congress approved. The whole activity aimed, in party jargon, "at getting a handle on the state apparatus." It manifested itself, among other things, in "distributing" 10,351 officials to different posts during the whole of 1922, 6,088 in the first quarter of 1923, 12,227 posts between May and December 1923. Uchraspred had its hands full, no doubt. The work needed some measure of predictability and this was hoped to be achieved by officially approved nomenklatura lists. We can quote the lists that were reworked and spruced up by CC decisions in November 1925. They were never made public. Initially, there were two of them, with posts listed in list No. 1 needing a final approval from the Central Committee, No. 2 needed coordinating with and an approval by the Uchraspred - or whatever name the Central Committee's department for cadres had at a given period.

Later, an additional set of jobs of "elective offices" was produced that had to be approved or pre-approved by special commissions selected by every body or congress where the procedure stipulated elections. Other jobs of some importance not included in these lists went into rolls that were prepared by government and lower party agencies themselves. They also did the nominating-dismissing because this was "their own" nomenklatura but, in some cases, "coordination" with the CC's Orgraspred was still needed.

One source containing Politbiuro decisions from March 1926 makes it clear that the Orgbiuro continued to work on the nomination procedures of candidates to posts of responsibility (otvetstvennye rabotniki) and that the procedures had to follow an institutional path - from CC's Secretariat, through the Orgbiuro and up to the Politbiuro with a distribution of prerogatives for each of these levels to have the last word on specified categories of ranks. ${ }^{5}$ The Politbiuro was the final arbiter on posts from the crucial list No. 1, after they were scrutinized by the two lower bureaus. This concerned both nominations and dismissals.

In mid-1926, list No. 1 contained 641 top positions of state and party agencies, followed again by an other list of posts in "elective boards and offices of central bodies" with 894 jobs in them. We know that "elective" positions had to be pre-approved in this system. We won't waste any irony on the obvious. Most of them were memberships in the Supreme Soviet's Presidium, in the Council of Commissars, the leading bodies of the Central, Russian and other "nationalities Soviets," and smaller numbers of leadership positions in agencies - seventeen in the Komsomol, fifteen in the central Trade Unions, twenty three in the branch trade unions councils. Institutions of lesser weight had no more than one or two leadership positions.

The government-party list No. 2 specified jobs - and numbers of jobholders for fifteen commissariats including the Supreme Council of the National Economy (VSNKh) and the Gosplan, three key banks, the Supreme Court, the military 
agencies (the "Revolutionary-War Council" (Revvoensovet), the Army's Political Directorate, The Chief of Staff, and Commanders of fronts and of military districts), the GPU, the Central Statistical Agency, TASS, editors of the central press, Executive Committees of the USSR and the Russian Federation, the apparatus of the Council of Commissars and of the Central Committee of the party. The latter included seven heads of departments, twenty positions in the Lenin Institute, twelve basic regional party bodies - and the party secretariats of Moscow and Leningrad.

The total of jobs in both lists $-1,535$ - represented positions of importance in all party-state governing bodies and agencies.

However dreary such enumerations, they give positions and numbers of the top governing layer and allow us to realize the relative simplicity of the administrative system of the NEP - compared to the later 1930s and the postwar period when listing top party and government bodies would take many pages. The respective nomenklatura lists expressed this state of affairs. There will be over 41,000 CCdependent nomenklatura jobs in 1946.

So much for the higher ranks. But we remember that lower but important bodies had their own nomenklaturas for officials under their jurisdiction. On November 16, 1925, all Regional party Committees and equivalent bodies were required to produce such lists of local (republican, regional, district) top jobs whose nominations depended on their own decision, or had to be negotiated (soglasovannye) with a higher body: a central ministry or a party body, according to the rank and importance of the job. The procedures could take on different forms. If the nomination was questioned by a local party organization, a CC secretary or head of Uchraspred would arbitrate and help reach a final decision.

Any changes concerning offices and officials from lists 1-2 had to be presented to the Orgraspred and get final approval from the CC.

Without questioning the very principle of a central nomenklatura, two top economic administrators, Bogdanov (VSNKh RSFSR) and Piatakov (VSNKh SSSR), disputed the scope of the CC's lists ${ }^{6}$ and requested more coordination of the nominations in question with leaders of these administrations - an attitude other top managers of administrative bodies certainly shared and probably criticized in private more sharply - although in those years it was still possible to do it openly too, before the CC.

The procedures of applying the lists to real life brought tens of thousands of people milling in the couloirs of the Uchraspred waiting to get their appointments, travel passes (putevki) or instructions. Many of them were not on the CC lists but not everyone understood the intricacies of the procedures. The offices in question turned out to look like "labor exchanges" (birzhy truda) or "a transit depot" (prokhodnoi dvor), or "a scramble" (svalka), as party members quipped and protested during a Uchraspred session. ${ }^{7}$ Speakers who took the floor during this

6. Ibid.

7. T. P. Korzhikhina, Iu. Iu. Figatner, art. cit.: 28. 
session (December 1926) in the CC building claimed that a privileged caste of party workers was being created in this way and there would be no safeguard anymore against the infiltration of "hangers-on" into the party - a fact that created "murmurs" in the ranks of conscientious workers. One speaker on the same session, after having quoted some relevant statistics, exclaimed: "how can we achieve a growing experience and professionalism when in just two years almost the whole pool of activists is being shuffled around, from place to place." Such 'shuffling around' (peretaskivanie), more neutrally called 'turnover' (smeniaemost'), was endemic in the nomination process and would remain so, at least, well into Khrushchev's days.

The nomenklatura procedures became extremely frenetic and ever more disorderly during the hectic 1930s, entirely disturbed and confused by the great purges, beginning after Kirov's assassination at the end of 1934. Parallel to the massive destruction of cadres, there went on a desperate and chaotic promotion to replace "enemies of the people" that were exiled, imprisoned or shot. Considering the scale of the upheaval, there is no reason to expect any orderly "cadres' policy" in those years, especially when the party's departments entrusted with conducting this business were being constantly purged themselves.

The personnel policies would have to endure some more upheavals, notably during WWII and immediately thereafter - we will mention those later. Suffice it to say for the moment that when peace came and such policies were put again on the agenda of the party apparatus, the theme was discussed as if the nomenklatura system had no precedents and was being established from scratch. In many other cases, when a state institution was being founded, precedents - notably from the tsarist past - were carefully considered. But the restoration of the by now "old" nomenklatura "technique" proceeded, apparently without referring to its past except for hints in passing that the "currently existing one" was never formally approved. That was somewhat puzzling in view of the fact that the two leaders who had "manufactured" and run this cadre policy since its inception, Kaganovich and Molotov, were still in top Politbiuro positions. Were they being snubbed because Stalin apparently groomed "an outsider" from Leningrad, the new secretary Kuznetsov, to become his heir without consulting his old acolytes? This is one of the possible speculations. There could be others.

\section{6: the turning point}

The 1946 "turning point" was initiated in order to reshape the party apparaty for the task of directing the country's administrative leadership towards peacetime aims: ideological education or re-education of the cadres themselves and of the population at large, mobibilization of the country to fulfill the first peace-time Five-Year Plan, in conditions of devastation and misery created by the war and by policy blunders. A few quite revealing phenomena concerning the party and its ruling techniques emerge from documents concerning these years. 
The pivotal department in the apparatus of the $\mathrm{CC}$ that dealt with personnel matters of all the upper ranks in state and party administrations was called at that time "The Cadres' Directorate" (Upravlenie kadrov) and we will refer to it as Upravlenie or Directorate for brevity's sake. This important party agency met with the new CC Secretary A. A. Kuznetsov (June 21, 1946), in a closed session, to discuss the state of the cadres' policy in the country and of this department itself. The source - substantial and quite unique minutes - offers a wealth of information, some of it quite startling. ${ }^{8}$ The session was closed even to important members of any other CC department. One such official was spotted and quite unceremoniously asked to leave. From the numerous speeches of the participants who took the floor, one could learn that consultations of this type - frank, all ranks present, comradely in tone and roaming over quite a vast panorama of problems and information - never occurred before in the department nor, as far as these participants knew, anywhere else in the rest of the party apparatus. Heads of Directorates or chiefs of sectors tended to do things "from above" without much consultation and this will become even more obvious to the reader, after he gets acquainted, later in this paper, with the CC's steep rank pyramid. Bureaucratic manners, it transpires, were ripe in the central apparatus itself - and one can sense from Kuznetsov's reactions to the complaints of the officials present at this session that he would like to do something about this. But the first point of order was the task ahead. Since the last CC meeting, a few months before, the whole apparatus of the party had been undergoing changes in an effort to improve its performance but it still suffered from many weaknesses.

During the war problems with and performance of the apparatus were not dealt with. The whole party structure was busy handling basically war-time, mainly economic tasks. The boundaries between institutions were blurred: "It was difficult to discern where the CC apparatus ends and where the apparatus of the State Defense Committee or of Ministries begins" - testified one of the speakers. The redistribution of cadres served war needs - and this proceeded apparently successfully. The Upravlenie selected and distributed 96,000 officials, always "on the double," as war requirements usually imposed. Moreover, many leading party officials were mobilized and were replaced by new people, including in this Upravlenie itself that was constantly plagued by endless shortcomings, in particular the absence of intra-departmental coherence. Its sectors specializing in different branches - the military, aviation, metallurgy, electrotechnical output - did not carry the same weight. Some, as the saying went in the Upravlenie, were "of substance," some others less so or not at all. Consequently, chiefs of the important sectors had access to the Head of the Upravlenie, they were "in" (byli vkhozhi, in Russian) - others were not.

At the same time, the very fact of working for such branches opened a window to a broader liability that could have been suspected by students of the system, but can now also be documented. To put it simply, such sectors of the party apparatus

8. RGASPI, f. 17, op. 127, d. 999. 
tended to become "an appendage" (pridatok) to the ministries. Ministers therefore felt that they could disregard those sectors or even the whole Upravlenie, even in matters of nominations of their top personnel (even if they belonged to the nomenklatura of the CC). Most heads of the Upravlenie looked on and were afraid "to step on the foot of important ministerial bosses, let alone of the ministers themselves." They mostly sided with the choices made by ministers and not with the ones of the Upravlenie's sectors.

As one would have expected, the knowledge of the cadres at large was scanty and the nomenklatura system must have been rather in abeyance. We learn that "nobody approved it, nobody examined it." Hence, thousands of important posts were vacant or were occupied by people who were not being approved for months, because "we did not know the cadres." By June 1946, 5,697 officials - 14\% of the putative (not approved) nomenklatura - had been on the job without confirmation, sometimes for about a year.

The way an energetic secretary like Kuznetsov would like this work to look transpires from his remark about the absence in the Upravlenie of a reserve of candidates for high positions. A candidate for a ministerial job was usually offered ten days after the request was made - when it should be offered, according to Kuznetsov, the very next day! An apparatchik's dream of a pushbutton supply of a minister or another chief, whenever the Politbiuro was looking for one. In the meantime, the reality was different. Officials were not being replaced fast enough or removed at all - whereas the situation warranted that many be removed urgently, including from the ranks of many deputy-ministers. Many nominations were made in a hurry - with sometimes catastrophic results. To illustrate the latter case, Kuznetsov shared a secret with his audience: "Why beat about the bushes? We are in a closed meeting today. We should say that it is also urgent to replace a number of ministers." One alarming example of the party apparatus' failure in supervision and judgment occurred during the war. "This is a very unpleasant, dirty business, but it must be told." 10 It turns out that during the war, the air force was receiving defective planes from industry. Numerous plane crashes and the death of many pilots could be attributed to this criminal mismanagement. The front frequently needed more aircrafts but thousands of planes remained grounded in airports, unable to fly. The thing was hidden for some years from comrade Stalin and the sector of aviation in the Upravlenie that had to control things did not react. They actually knew but kept quiet about it.

Obviously, those directly involved in the affair were punished - but Kuznetsov did not elaborate. (At that time he did not know that the accusations against the Minister of Aircraft Building and other officials were bogus - most of them survived miraculously and were rehabilitated under Khrushchev.) What counted for him was the fact that the Upravlenie still did not know the cadres well enough, continued to offer unworthy candidates for important positions - and next was

9. Ibid., 1. 21-23 and passim.

10. Ibid. 
ashamed to admit its error or tried not to wash its dirty linen in public. Many "flops" were cited - nominees who did not cope, or who actually were released from camps after they did their time for trotskyism or some other reprehensible transgression. What irked Kuznetsov most was the fact that the firing of such people was initiated by Abakumov (Head of the secret police), when the initiative should have come from the apparatus' Upravlenie.

\section{The new approach}

The minutes of the Cadres' Directorate meetings and other sources offer the outline of measures the Politbiuro envisaged in order to put its own house and its cadres' policy at large in order. ${ }^{11}$ Hence, an effort to redefine the functions of the whole apparatus, to clarify the division of labor among them and, not less significantly, to change the way the central apparatus dealt with the economy. Astonishing as it might have sounded, this apparatus was now to shun direct involvement in the details of economic management and of those managers' performance! From now on, functions and spheres of action between party and state had to be redefined and separated. The $\mathrm{CC}-$ it was now clarified - was a policy setting body (direktivnyi organ) - it provided guidelines or directives to the Government. The apparatchiki were, clearly, baffled to hear that the $\mathrm{CC}$ would no longer deal directly with economic problems. In fact, economic departments in the CC - like the one for agriculture or transportation - were being liquidated. The orientation was now for the apparatus to deal mainly with the party itself and all top cadres - without looking into their basic branch activities and performance. The CC would, of course, continue to give directives to the government, including on the economy. In addition, through the supervision of the cadres, problems of economic performance will keep coming up, so to speak, indirectly. Local party organs on the other hand - like the Regional party Committees (obkomy) that carried out "executive" (ispolnitel'nye) functions - should keep the economic sectors in their apparatus and continue supervising the economic sphere as before. Obkomy should not copy the structure of the CC.

In an effort to introduce some clarity into the ever more obscure frontiers between the top two bodies just below the level of the Politbiuro, it was now stated: the Orgbiuro will deal with local party organs, call them in and listen to their reports, propose improvements - though this was not how the Party Statute previously defined its task. The Orgbiuro was a body working in regular pre-set sessions or meetings (zasedaiushchii). The Secretariat, on the other hand, was a permanently working body that met every day, at any time of the day, as needed. Its main functions consisted in preparing the agenda and the materials for Orgbiuro meetings and in checking the execution of decisions made by the Orgbiuro and the Politbiuro. The Secretariat was also to be responsible for the distribution of leading 
cadres all over the system (through the appropriate TsK departments). Helping local party organizations to control effectively state and economic organs, criticize them, be political leaders of the masses, was now the main objective of the top party leadership and those were the terms they used.

What caused this kind of reorganization, "away from economics"? We were offered only a hint so far - but the depth of the problems demands an elaboration and the documents are not shy: massive facts, from many sources, Kuznetsov's obvious urge to air the problems frankly - "we are among ourselves here" point to a far from rosy picture in local party bodies, i.e. in any party organization below the CC, but even the central apparatus itself was in the danger zone.

The main cause for alarm was the widespread phenomenon of the subjugation of party officials to economic ministries.

One aspect of this subjugation was sometimes called "self-supply" (samosnabzhenie), which covered different and widespread practices. Heads of state agencies - especially the economic ministries or their lower agencies, offered, illegally it turns out, financial inducements like premiums, prizes, bonuses, valuable gifts, endless services (dacha building, home improvements, places in fine sanatoriums) for local party secretaries and their families - all from ministerial coffers of course, i.e, from state coffers. This economic cushioning of the party elite "took on very vast proportions," our source states. ${ }^{12}$

More material about this comes from another Kuznetsov document from the latter part of $1947 . .^{13}$ The PB had just issued a stern decree against the practice of party people being given premiums by economic managers. During the war, the practice was generalized - and it went "from top to bottom." Moreover, in conditions of food shortages and low living standards - in 1947 it was more like famine, rather than just low living standards - , there were numerous cases of party bosses from the party hierarchy actually engaging in illegal so-called "pobory" (meaning requisitions, if not extortions, of food, merchandise, etc.) from economic organizations. These, of course, were crimes. Such practices, again according to Kuznetsov, "are in essence a form of bribe that puts the party representative in a state of dependence from economic agencies." 14 This means that the interests of the agencies were served to the detriment of state interests. The defense of state interests against any particularism being the task of the party, how can party officials defend those interests if improving their own material situation depends on bonuses and benefits from economic managers or other administrators?

Ministries were putting party bosses, including highly placed central apparatus leaders in all the regions of the country, on lists for remunerations - "and this is wrong," said Kuznetsov during the 1946 meeting with the Upravlenie..$^{15}$ Massive facts about these practices were uncovered and reported to Stalin not by the party

12. Ibid., 1.8 .

13. RGASPI, f. 17, op. 121, d. 572.

14. Ibid., 1. 10.

15. Ibid., f. 17, op. 127, d. 999, 1.9. 
apparatus - we already know that this causes a high party secretary to wince but by Lev Mekhlis, Minister of State Control.

The central apparatus knew all this but did not report because they did not ascribe much importance to such behavior. It was, as we just learned, so widespread that they - we surmise - got used to this. Stalin supposedly declared that such usage of national resources was a crime. "Bribes" create cozy "family" relations, party bodies become playthings in the hands of managers. If continued, such a shameful situation would spell ruin for party people.

Whether such wording really came from Stalin, or was Kuznetsov's own, the problem and the task were stated quite dramatically: "Party organizations must regain their independence" (Partiinye organizatsii dolzhny stat' nezavisimymi) ${ }^{16}$

This alarming situation was the underlying reason for the decision to take the central party apparatus out of the economic activity and to restore the party's proper functions as the leaders saw them: going back to controlling everyone's cadres but no longer being directly involved in economics. The menace of a monumental sellout of the political agency to the economic ones required urgent action. It would not take long to realize that the directive "to get out of the economy and go back to party work" would produce complicated side effects.

The picture we just contemplated had, as we already hinted at, yet another twist to it, although the source was the same. In addition to the loss of power as result of "getting bribed," there was yet another "leakage" in the supposedly tight party-dominated system - ministries tended to disregard nomenklatura rules in many ways and did not respect the Upravlenie very much ("When did you see a minister coming into the Upr. kadrov lately?" asked one discussant. This was met by an interjection: "And when did you see his deputy here?" - which brings us again, in this context, to the same outcry from the apparatchiki: "We lost power!" - stated one of the speakers. They certainly realized that if ministries treat nomenklatura rules so carelessly and sometimes just do what they wish with and to it - what other means exist to control them, what other functions can the Upravlenie possibly have? Kuznetsov confirmed expressis verbis at the end of 1947: ministries treat the central nomenklatura "in an unacceptable manner." More broadly, "The habit of nominating and dismissing officials that were included in the Center's nomenklatura without the approval of the Central Committee took on unacceptable dimensions." ${ }^{17}$ A number of ministries made 70-90\% of their staffing decisions on positions included in the Central nomenklatura without informing and asking for the CC's consent. They did ask for authorization much later, when the people in question were already either in or out. Now the Central Committee requested that the Upravlenie put an end to this practice. From now on, proposals of changes of jobs or their listing in a nomenklatura of a particular level of the government hierarchy should be discussed in the appropriate CC institution. In all cases, the Upravlenie should begin the procedure and next, depending on the

16. Ibid.,1. 10-11.

17. Ibid., f. 17, op. 121, d. 572, passim. 
importance of the job, the case would go higher up. The Upravlenie should, in cases of transfers or dismissals, deal simultaneously with candidates for replacement. Ministries do have the right to propose these changes, and the Upravlenie is warned that it should not make decisions of this kind inside its own apparatus (apparatnym putem). The matter must be submitted for final decision to the CC.

It is clear from such materials that the procedure did not automatically entail sending in nominees chosen unilaterally by the CC. The government agencies themselves were involved and probably suggested most of the candidates for nomination. Except in cases of a big failure and crisis in some ministry, or when an entirely new agency was created, new leaders might have been sent in from above by the $\mathrm{CC}$ apparatus.

Another weak link of the cadres' policy stemmed from the endemic weakness of the cadres' departments that existed in every ministry. A special post of deputy-minister for cadres was created by Politbiuro decision in 1938, but they did many things except running directly their personnel department. The problem was actually studied by inspectors who found that in 48 out of 57 ministries and other government agencies, deputy-ministers did not interview candidates for jobs, did not bother to staff personnel departments with qualified officials, did not assign them to adequate offices, did not approach the $\mathrm{CC}$ with any problems concerning this whole sensitive activity. Not to mention the fact that the crucial precaution of having a list of candidates on reserve, as was prescribed to them in 1946, was neglected. ${ }^{18}$

A CC decision was, of course, enjoining deputy-ministers to mend the deficiencies of their cadres' departments, to stay in touch with party bodies of the appropriate level. The Upravlenie, naturally, should look for better candidates for those jobs of deputy-ministers for cadres - although all these measures had to be taken in consultation with the respective leaders of the concerned government agencies.

Again, an additional revealing feature emerges in this context: ministries tended to discuss and decide nominations with their direct superior - the Council of Ministers with whom they handled most of their other important problems. So the cadres' problem would also pop up, "as one would say, somewhere in the vicinity of items like metal, cement and timber," quipped Kuznetsov, leaving the CC out. ${ }^{19}$ From the party's point of view, such shortcomings in cadres' policy, made a string of major failures unavoidable. In many ministries, cadres were selected on "grounds of family ties." The source gives numerous examples: bosses hired their relatives and covered up for their incompetence or even for their misconduct, offered jobs to pals with criminal records, hired thieves or would-be thieves, others who soon turned out to be traitors (and flee abroad...), nominated weak people, without principles, bootlickers who contributed to an impression of efficiency but hid their failures from the CC. The worst offenders were to be found, probably, in

18. Ibid., 1. 242, 246.

19. Ibid., 1. 236-239. 
agencies dealing with supply and commerce: "cadres are selected here, as a matter of common practice, on the basis of personal acquaintance, sale and purchase of positions, and also on grounds of common ethnicity." 20

The list of personal and institutional misconduct all over the state administration was long. Obviously, a strong intervention was needed. The implications were the reader certainly noticed - that this heavy price was attributed to the tendency of state officials to handle cadres among themselves, or to defer to the Council of Ministers, thus escaping the party's watchful eye. But the watchful eye - the Central party apparatus - was not innocent and could not be left out from the Secretariat's indictment. The absence of proper oversight was the fault of officials from the Upravlenie although they were part of the Central party apparatus - the system's sancta sanctorum, not less, as was sometimes preached to apparatchiki to make them do their work with a deeper sense of their mission.

The material we have presented so far has unveiled features of the system that were overlooked or misunderstood before. They pertain to the nature of the Soviet bureaucracy and the problems it created for the party. The idea of a "nomenklatura," a "ruling class" composed of all those nominees, tightly controlled from above, actually helped miss deeply seated trends and fissures that the party had to deal with and never managed to overcome.

\section{The nomenklatura: a renewal}

\section{How was the apparatus reorganized?}

The CC secretary A. A. Kuznetsov appeared before a closed meeting of directors of party schools towards the end of 1947 , and presented to the audience the reforms in state administrations and the party's own apparatus that had been launched a year before, adding more details on this occasion to clarify the rationale of the "new line." 21

The work done so far aimed at a "perestroika" of the managerial structures of state administrations, notably in the economy where a great number of factories that worked for the war turned to civilian production. The perestroika going on simultaneously in the party apparatus aimed at streamlining these party bodies to be able to effectively guide the state apparatus during a difficult transition to peace-time reconstruction. It is interesting to note that whereas the principle of efficiency in the state machinery dictated the need to break up many oversize ministries into smaller agencies, the opposite principle seemed to be more expedient inside the party apparatus. The party had to concentrate on launching and propagating the first postwar Five-Year Plan. The previous slogan of "everything

20. Ibid.

21. Ibid. 
for the front," was to be replaced by "everything for the Five-Year Plan," which seemed like the best set of objectives to unite the population around. That was important in view of the fact that the $\operatorname{VKP}(b)$ had no (formal) program. A program commission was established by the XVIII Party Congress (its work was probably interrupted by the war). "Our program consists, in substance, of Stalin's Constitution and the FYP" - a rather ambiguously sounding statement from a CC secretary. ${ }^{22} \mathrm{He}$ could not have stated anything like that without Stalin's preapproval or direct instruction, which allows us to surmise that Stalin did not need party programs anymore - he was the program.

In this meeting with party school directors, a clear division of labor was established between the CC and the Council of Ministers. The CC no longer intended to handle economic problems directly. A streamlined Upravlenie would now be entrusted with handling all the leading personnel of state administrations and of the party. All this required reorganization. If the party apparatus was in considerable flux almost all the time, the basics always remained, more or less, the same. This is why the structure entrusted with handling cadres that emerged in 19461947 is sufficiently instructive for us to delve into in some detail. The Director should have five deputies. The Upravlenie, instead of its 50 departments (otdely) would now have $28-$ a group of ministries and other agencies being assigned to each of them. There would be one registration department for the whole Upravlenie and several other service sectors. Among the 28 departments, one for cadres of party organizations, another for soviet institutions, for the armed forces, for training and retraining party cadres, for internal affairs, foreign trade, one for the complex of state security-prosecution-the judiciary, another for communications, a sector for each of the main branches of industry, as well as agriculture, finance and trade, higher education and science, publishing, art... A very complicated Upravlenie indeed, and a rather bulky one, employing about 650 officials. Probably the biggest in the CC apparatus - until new changes, only two years later would send the whole apparatus back to an earlier functional-economic pattern.

By the beginning of 1949, the specialized branch sectors of the Upravlenie were transformed into separate independent departments. Officially they would just deal with the cadres in these branches. In fact, such CC departments would continue to get enmeshed, volens nolens, with the managerial structures in the economy because of the very character of the branch system - a phenomenon that the 1946 reforms of the apparatus tried to forestall. Thus, what was supposed to be a turning point in 1946 became "a returning point" two years later. This will become clear when we look somewhat more closely at several features of this "return."

Instead of the bulky Upravlenie for cadres and the more narrowly specialized department for inspecting party organizations, ${ }^{23}$ a new scheme made its appearance. Another document (that has no date, but is probably from the

22. Ibid., 1.228.

23. The "Orginstr" was also reorganized, having recourse to inspectors recruited from the best ex-regional or other experienced medium-level secretaries. 
beginning of 1949) explained the organizational chart: the apparatus of the CC (under the overall guidance of, mostly, the Secretariat and an important role in it for the Orgbiuro) supervises and deals with problems pertaining to the working of central government agencies (115 ministries) and organizations (republican and regional party bodies) that are distributed among the new CC departments. ${ }^{24}$ It was not going to be an easy task for any of them in view of the fact that each of those state agencies engendered multitudes of local branches and especially incoherent supply-and-marketing networks that proved problematic to every and any inspecting agency. Consequently, the object of the apparatus' supervision was an ever more complex labyrinth of networks.

Each of the apparatus' departments had its own internal structure with varying degrees of complexity, and each one had its own registration unit. But there also was a service structure common to the whole CC. These general "supervisory departments" included the statistical service, but also coordinating departments like the general secretary's "special unit," a secret and an encoding sector, and different "groups" and "special officers" not well known to outsiders, including a group for serving foreigners, a separate "department of the CC" (possibly an auxiliary secretariat for the Orgbiuro?), a pivotal "General department" through which all important papers and assignments "traveled" to and from the other departments, a "Business office" (Upravlenie delami), a public information group for responding to letters, a group dealing with the "unified membership card and membership registry," "a commission for travel abroad," a special "Kremlin group," a unit dealing with "auxiliary farms" (probably part of the Business Department that also had a car-and-technical sector).

As we can see, the organization chart of the country's power hub was anything but simple. But before we raise the question whether it was adequate for the immensity it was supposed to oversee, a detour into the regime's ideological trends of the times may be useful.

\section{The Zhdanov context}

The spirit of the policy of Zhdanovism also made a deep imprint on the life of state administrations and of the party apparatus itself where large numbers of educated people were employed. The introduction into top party and state agencies of the archaically sounding "Courts of Honor" squared poorly with any solid administrative logic and mightily interfered with substantive efforts to improve the professional level of the state and party apparaty. These "Courts" were supposed to instill in the apparatchiki a sense of patriotism and pride in the unique achievements

24. Among them: propaganda and agitation, party-komsomol-trade unions, international relations, branch departments for heavy industry, light industry, engineering (machine building), transportation, agriculture, and a powerful new "administrative" department for handling the cluster of security agencies and the cluster of agencies in fields of planning-finances-trade. RGASPI, f. 17, op. 121, d. 572. 
of their (Stalinist) fatherland through staged mock trials inside the agencies. The culprits would be accused of all kind of infamous behavior - but mostly only careers would suffer. By official recognition, such "courts" would deal with "crimes" charged with treasonable connotations, yet not subject to criminal prosecution. ${ }^{25}$

The explanation of this policy by Kuznetsov, who had to reorganize the apparaty, in a report he presented to the full body of the party apparatus (September $29,1947)$, makes it clear that the operation was aimed at the educated layers - the intelligentsia - including the growing number of specialists. ${ }^{26}$ The central apparatus was not considered immune to the disease and the meeting was convened in order to elect the aforementioned "Court of Honor" for the CC apparatus, and thereby inaugurate elections of such Courts in every administrative body of the country. Their declared aim was to combat behavior that exhibited "crawling to" or "fawning upon" the West.

A "Court" was created also in the Ministry of State Security, whose operatives were seemingly irked by the implication that they, of all people, should need such a "court," but Kuznetsov told them (during a separate meeting with them) that if the party - the country's main citadel - needs one, then the MGB had no reason to lag behind it. ${ }^{27}$ Thus, security agencies needed, like any other body, the immunizing stuff these "Courts" were supposed to instill: a patriotism and a certain "spiritual independence" that were based on realizing the superiority of Soviet culture over the Western one, etc.

The hoped for turning point in the moods and consciousness of large chunks of the "contaminated" Soviet intelligentsia should begin, in the first place, in the apparatus of the CC. The document allows us to peep into some of the neuralgic spots of this apparatus. The work of the country - so runs the argument - depends on the quality of the party apparatus. The "Courts of Honor" should be important here. The apparatus was harboring numbers of employees who indulged in anti-patriotic, anti-social and anti-state transgressions. When cases like that became known, they tended to be handled internally, in a close circle, without publicity. This stemmed from the widespread belief that once a person was an apparatus insider, vigilance towards him and need of political betterment do not apply anymore. But many of them failed to understand that work in the party central apparatus - the system's sancta sanctorum (the text states this, as often on other occasions, though not in Latin) - is not routine employment. ${ }^{28}$ It is a party duty. And yet, dissolute behavior was observed even among leaders in the party apparatus - absolutely inadmissible

25. The "Courts of Honor" were abolished or lapsed some two years later, as happened somewhat later, to the ridiculous uniforms and antiquated bureaucratic ranks and shoulder straps that were imposed on ranking officials, common in spirit to the "Courts of Honor" and part and parcel of the dark ages of "Zhdanovism."

26. RGASPI, f. 17, op. 121, d. 572,1.110 and passim.

27. Ibid., 1. 217-218.

28. Ibid., 1. 182. 
in party ranks, let alone in the central apparatus. Drinking, sexual licentiousness, careless handling of secret party documents were among the most frequent misdeeds cited here. But they were dangerous because the $\mathrm{CC}$ received data on all aspects of the country's activities - including defense and foreign relations. This is why, quite independently from the position held, the work done in the party apparatus was confidential. Vigilance was the main tool of the party's fight against its enemies, and an unbreakable principle of the country's life.

The official policy, at least as announced to the central apparatus, drew its inspiration from the methods of the great purges, suffusing it with a particularly sinister connotation. Some of the key sign-posts of this policy of the "great purges" were listed as useful reminders. Among them the "closed" letters to party members that launched those policies - dated January 18, 1935 - concerning actions against "Kirov's murderers"; the July 29, 1936, circular about the Trotsky-Zinov'ev "terrorist block"; the May 13, 1935, letter about party membership cards; the June 29, 1941 , circular to party and state agencies in the districts near the front - all of them preceding or following terrorist waves against the country's population and especially the cadres themselves. The shadow of the sinister policies was deliberately invoked to serve as a warning against the potentially disloyal intelligentsia.

All this was brought to the attention of the cadres to make them understand the spirit of a campaign aiming at inculcating no less than "independence of mind." The foreign espionage factor was also put to work. International espionage tries to penetrate the party apparatus - when they do not succeed, they go after the apparatchiks' family members. You tell your wife, she tells a neighbor - and everyone gets wind of confidential state matters. One example, particularly jarring for party leaders, concerned the 1948 top-secret government decision to raise prices. The fact became known to the population beforehand and caused a panicky rush on every open or presumably closed store. All because of "family chatter-boxes" from the party apparatus. ${ }^{29}$

The purges accompanying this "Zhdanovism" did not take on the scale of the 1936-1939 persecutions, they nevertheless produced such atrocities as the destruction of Jewish writers, numerous arrests (and some deaths) of cultural figures - not to mention many broken individual careers and destroyed works of art and science. In 1950, the so called "Leningrad affair" was tragically concluded by putting to death the former leadership of the Leningrad party and state - first among them Kuznetsov himself, and the deputy Prime-Minister and Gosplan Head Voznesenskii...

All this is important to us in order to understand the atmosphere that suffused the country and the party, at the time when the same CC secretary, from whom we just learned about the essentials of "Zhdanovism," also wanted to do the important job of rationalizing the work with cadres. The difference in tone and spirit between Kuznetsov's presentation of the official ranting in 1947, and the tone of his frank and reasonable discussion with the Upravlenie a year earlier is striking. 


\section{An administrative way to save an administration}

The reorganization of the apparaty in itself seemed not to be directly connected to the themes instigated by "Zhdanovism," intended to provide indoctrination for a renewed ideological monolithism and fervor in a society tired by years of industrialization, collectivization and war. The administrative changes on the party's agenda, although related to war events, seemed to react to different classes of phenomena. The "economization" of the party was the name of the game that alarmed the leadership more than ever before. What seemed to be at stake in this context was the very existence of the party as a ruling institution. During the war, processes leading to its becoming "an appendage" to ministerial managers and losing their own power were deepening. No wonder - they were in fact being "paid off" or "bribed" by the managers, who also tended to defer more to the Council of Ministers and to pay ever less attention to the nomenklatura of the CC. Data on not heeding these rules abound.

Extricating the central apparatus from direct involvement with economic agencies, except with regard to general guidelines and cadres, seemed to be the remedy for the disease. The "Zhdanovism" factor seemed to suggest a solution. The Upravlenie had previously preferred to recruit technically trained people (tekhniki) - now "humanists" ("gumanitarniki": graduates in the humanities) would be favored in order to catch any ideological slips, such as "alien" passages in an opera, or the publication of a poorly scrutinized Lenin biography. "Technicians" could not understand, let alone combat ideological subversion. A menace like the "economization" of the party - something much more prosaic but less obvious that began to be seen as dimming the party's ideological outlook would be entirely beyond the wit of such "technicians."

"Getting out of the economy," and presumably into politics and ideology, required an answer to the question: what exactly was the ideological framework that was seen as losing its vigor? And what could be counterposed to western capitalist influences? A line like "getting out of the economy" could not, in itself, serve as an ideological underpinning for badly needed reinvigoration of the system.

We are touching here on a nerve center in the party's ideological armor at its moment of glory after the victory over Germany. Stalinism at this stage could not and did not wish to criticize capitalism from socialist positions anymore - it clearly lost for good this ideological coagulator which was also implied in Kuznetsov's cryptic statement that the party "has no program" but the Stalin Constitution and the Five-Year Plan. It would certainly be imprudent for leaders selected by Stalin to raise with him a problem of such import. The terms of "losing out to managers" might have been suggested by Stalin himself - but implying that under him the party lost its original ideological vigor would be suicidal. But here certainly was the root of the "economization" of the party's cadres. Stalin himself was aware of it. The policies of "Zhdanovism" were certainly undertaken at Stalin's behest, proving that he was aware of the ideological weakness of the regime and 
decided to offer a different ideological "coagulator" and mobilizer. Our sketch showed what this consisted of, a virulent kind of nationalism, replete with ideas akin to fascism. But it was part of the malady, rather than a cure.

In any case, the reforms imply that a better division of labor between the $\mathrm{CC}$ and the Council of Ministers could initiate a cure. The Council of Ministers should run its show (of running the economy - among others) - the apparatus of the CC should mind the business of staffing key posts and oversee the activity of cadres' departments of all institutions.

Be that as it may, the 1946-1948 efforts at an administrative reshuffling of the party apparatus were also indicative of the nomenklatura as a technique, and of its problems till the end of the regime's existence, independently of other ongoing or changing political and ideological circumstances.

\section{The nomenklatura of the Central Committee: a sociological approach}

The resurrection of the Central Committee's nomenklatura list was a key device that exacted a massive effort from the Upravlenie and from the apparatus' three superior bureaus - Politbiuro, Orgbiuro (abolished in 1952) and the Secretariat. We can now examine "the list" more closely - and next figure out how it was supposed to be enacted in practice.

A document signed by Andreev - head of the Upravlenie - and by Revskii, his deputy, on August 22, 1946, addressed to four secretaries of the CC - Zhdanov, Kuznetsov, Patolichev, Popov - , presented a version of the nomenklatura list ${ }^{30}$ - but we should remember that the data fluctuate somewhat from one version to another. The list included 42,894 jobs that its compilers praised as being better adapted to the needs of the Five-Year Plan for 1946-1950. The Upravlenie was also working on the much needed, so-called "reserve registry" - an auxiliary list of candidates for nomenklatura jobs in case of a rising demand. The latest version of the renewed nomenklatura eliminated about 9,000 positions from the previous rolls. Many exclusions and inclusions were necessary to account for changes in economics and technology and the concomitant changes in the relative importance of the different jobs.

It took about three more months for the first (post-war) "Nomenklatura of posts of the Central Committee" to be approved, in stages, in October or November 1946 - offering the apparatus a document that could now serve as CC's blueprint for working with top cadres. The Upravlenie delivered for this purpose not just a list of posts to be filled according to this nomenklatura's rules. They also produced quite a detailed study of the officials who were already holding these posts at that time. 


\section{A sketch of the bureaucracy}

This informative document - now referring to a total of 41,883 positions (and officials) - allows to compose a "portrait" of the whole cohort considered most sensitive in the system. ${ }^{31}$ The classification offered is laborious and detailed. First, an enumeration of the jobs the CC wanted to see "on its own nomenklatura": the first place is taken by "posts in party organizations" mentioning all the positions and ranks - from CC Secretaries and their deputies to heads of departments and their deputies, heads of "special sectors and cipher clerks." The same was true for republican and local party bodies, directors of party schools and chair holders in marxist-leninist history and economics. And so, down to the lowest district level.

The same work was done with all posts of the state apparatus (central, republican, local) - ministers and their deputies, members of ministerial collegia, chiefs of all the directorates and a long list of jobs down the ladder in government administrations, as well as in the separate machinery of the soviets, to the lowest rank the $\mathrm{CC}$ still wanted on its roster.

The numbers of posts involved in each ministry are also available, but grouping them by hierarchical categories is more revealing: out of the total of 41,883 "nomenklatura positions," 4,836 were in the central apparatus of all the top-level administrations. This top stratum - some $12 \%$ of the nomenklatura list - should be confronted with data taken from the Central Statistical Office detailing the totals and the categories of the whole state apparatus. ${ }^{32}$ The CC list turns out to have included about one third of the very "first league" of bosses about 160,000 strong - 105,000 of them working in the central governmental apparatus, located mostly in Moscow, with an additional 55,000 working in central administrative bodies (ministries and agencies) of the republics. It means first that the big mass of officials with managerial ranks were included in nomenklatura lists of institutions below the CC level. "The first league" is only a part of the overall number of bosses, high and low, big and small in the country's administrations at large that comprised at that time about 1,6 million posts $(18.8 \%)$ out of a total of 8,6 million employees. But the smaller number of about 6,5 million, by excluding about 1,5 million of auxiliary personnel (technical staff, cleaning ladies etc.), is more appropriate to better locate the administrative personnel proper. Included in the "leading" or "top managers" category were officials running administrative units with lower rank subordinates reporting to them, or those who had titles (probably also the role) of "principal" (glavnyi) or "senior" (starshii) specialists (glavnyi inzhener, starshii inzhener).

Returning now to the CC "nomenklatura" (part of the "leading" cohort), we are offered different breakdowns by the structural units they ran or by the broad field in which they operated. The latter classification shows that the biggest chunk of the

31. Ibid., d. 1628, 1. 40-57.

32. "Predvaritel'nye itogi," written on March 29, 1947, to Voznesenskii (deputy Prime Minister) by Head Ts. S. U, V. Starovskii, RGAE, f. 1562, op. 329, d. 2332, 1. 64-68. 
CC nomenklatura roster were Party-komsomol officials $-10,533$ in all $-24.6 \%$ of the total list. Industry had 8,808 positions $-20.5 \%$; agencies of state power and of general state administration had 4,082 positions (9.5\%); state defense bodies 3,954 (9.2\%); culture, art and science - 2,305 (5.4\%); transportation $-4.4 \%$; agriculture $-1,548(3.6 \%)$; state security and social order $-1,331(3.1 \%)$; procuracy and justice $-1,242(2.9 \%)$; foreign relations - 1,169 (2.7\%); construction enterprises - 1,106 (2.6\%); procurement and trade - $1022(2.4 \%)$; social services $-767(1.8 \%)$; trade unions, cooperative societies $-763(1.8 \%)$; state planning, registration and control $-575(1.3 \%)$; financial and credit institutions - $406(1.0 \%)$.

A general reader may not need such details. The one that happens to take a special interest may find here some food for thought about controlling techniques, the logic and illogicalities of a centralized staffing policy. A broader professional profile of officials holding CC's nomenklatura positions in mid-1946 is also revealing: 14,778 of them were engineers of different specialties. Less specialized knowledge among many of the others was compensated (it is claimed) by length of service. $70 \%$ of those who had only primary education, had more than ten years of service in leadership jobs - a datum that lends itself easily to less optimistic conclusions. In general, 55.7\% of the central nomenklatura cadres did have a service experience of over ten years. The nomenklatura included even some non-party people $-3.5 \%$ (about 1,400 job holders). Such professional levels were, of course, inadequate and a vast campaign was afoot to raise the professional standards of the higher-level cadres by accelerating the training of specialists with higher education, notably in the higher technical schools and in universities. This concerned the whole administrative cohort. The educational level of a good half of the whole state apparatus - including the category of "specialists" - was still low in 1947, and would improve considerably over the post-Stalinist years.

Last but not least, the national composition of the "leading" cohort is significant. For the whole list Russians represented 66.7\%, Ukrainians - 11.3\%, Jews $-5.4 \%$ etc. ("etc." is in the source). In the group of the "zamy" - a pivotal group of officials -: $80.4 \%$ were Russians, $7.3 \%$ were Ukrainians, $2.1 \%$ Belorussians, $6.4 \%$ Jews, and among the Heads of Main Directorates (nachal'niki glavnykh upravlenii) - another crucial group inside the top brass $-72 \%$ were Russians, $11.5 \%$ were Jews, $9.6 \%$ were Ukrainians, $2.5 \%$ Belorussians, $1 \%$ Georgians, $1.6 \%$ Armenians.

\section{How was this supposed to work?}

Rules and decisions on the functioning of the nomenklaturas of party and other administrative bodies allow us now to talk about the nomenklatura in the plural.

Nomenklatura lists existed on all the hierarchical ladders - the number of jobs to fill was not 41,000 but more than a million. Party and state bodies were supposed to handle their own nomenklaturas through a three-pronged procedure. Depending on 
the status of the jobs involved, they could make their decisions alone, or make proposals for firing and nominating, the final decisions to be made higher up. Hiring and firing of a third group of jobs had to be "coordinated" or negotiated with the higher or lower interested agency - before the final approval was given by the level properly authorized to do this. All these procedures concern the nomenklaturas of party and government agencies other than the CC. But even the nomenklatura of the CC was in itself subject to "layered" decision making. An inkling into these procedures can be gained from a project of $\mathrm{CC}$ procedures concerning its own nomenklatura list. Nominations, transfers and dismissals from positions listed in CC nomenklatura jobs could go into effect, formally, only after the CC approved them. But heads of the authorized agencies - like the Central USSR and Republican Ministries - did propose candidates for CC nomenklatura posts, and so did ministers and other heads of institutions on each level of the administrative ladder, who commanded a nomenklatura of their own. They listened to or offered proposals for nominations and clearly had a bargaining power in these matters, not only with the party bodies below the $\mathrm{CC}$ but also with the $\mathrm{CC}$ and its highest bureaus.

On the local level, again, a similar procedure was to be applied. In cases when there were differences between party bodies and ministries or local soviets, they turned for arbitration to the $\mathrm{CC}$, each side with their respective proposals. All administrations were obligated to regularly present current materials that characterized the work of CC nomenklatura nominees and an expanded assessment for every individual at least once a year. Regional party committees were expected to deal with cadres of their own level but also help the CC to learn about and appoint leading cadres to jobs of central importance, by reporting in due course on weaknesses and merits of leaders of organizations they had knowledge of.

In the framework of the 1946 revamping of nomenklatura rosters, all party and state administrative bodies were required to revise and present their own nomenklatura lists for approval to the CC by October 15, 1946.

Here is one example: the Moscow Party Committee - an important hub of nomenklaturas. The "house-keeping" by this Committee of its personnel matters, was certainly more complicated than in any USSR ministry - Moscow was almost a mini-state. Its own top brass was on the CC lists, and a somewhat lower layer of officials - on its own. The three-step decision making applied here too, depending on what and whose nomenklatura the ranks in question belonged to: for some jobs, the right to a final approval was in Moscow Committee's own jurisdiction, others (obviously of a higher level) depended on a shared decision making, probably with the CC Secretariat, for the very top positions - bargaining with some level in the $\mathrm{CC}$, but final approval made there. The Moscow first city party secretary, maybe even the second, were directly dependent on the Politbiuro.

In 1947 the Moscow City Committee enlarged its nomenklatura lists by adding numerous positions in the city's district committees to the City Committee roster, as well as secretaries of party committees and bureaus inside all of the ministries and other central bodies residing in Moscow. Party secretaries in crucial enterprises, offices and academic institutions in the city were also included. All this amounted to a 
considerable accretion of Moscow's party's power. (This is detailed in a 1947 report by the Upravlenie on the work of the otdel kadrov of Moscow's Party Committee.)

The whole nomenklatura depending on the City Party Committee had a list of 4,309 positions, 2,727 were approved by the Moscow party bureau, 708 were negotiated in the City Committee's own cadres' department, 874 had to get final approval in the CC. $96.2 \%$ were party members, $0.4 \%$ candidate-members, $3.4 \%$ non-party.

We probably got by now the gist of the procedure and its triple-level distribution of jurisdictions. But we also know that these or other procedures and rules were not necessarily followed, not least because of their complexity and unavoidable fuzziness. In any case, important ministries and other agencies, or important cities and republics (their Central Committees, their Council of Ministers) had an input in what the PB (or Secretariat, or just the Upravlenie or other cadres' departments) would endorse - they were, as we already know, actually asked to "help" - i.e. that either they made proposals for final approval upstairs or they could - quite effectively - dispute a candidacy proposed from above.

In sum, what we get is a maze: some actions are taken according to rules and others occur simultaneously according to informal, surreptitious or illegal practices - the picture of some monolithic and uniform tool of the party's Center gets replaced by something much fuzzier.

\section{The final stage - organization and registration}

Nomenklatura lists were frequently changed and shifted according to changing circumstances and multifarious pressures. Pressure could come from agencies, especially new ones, to have their top brass included in the CC list or, to the contrary, insisting that some categories of jobs, especially high-profiled specialists who had a considerable bargaining power and were often needed urgently, be excluded from the list. Nomenklatura procedures were too rigid in these cases and they often constrained the maneuverability and the power of important, especially science-engineeringbased branches. Political and ideological reasons also abounded when decisions of inclusion-exclusion from the Central nomenklatura were concerned.

The vast enterprise of providing and controlling leading personnel entailed an enormous ledger and file-keeping husbandry. Registering-reregistering, gathering data on so many people, updating their files, studying those who work already and those still on reserve lists - these operations for which the Upravlenie served as the main "smithy" were described in a chapter "The registration of cadres," which included a report by the Upravlenie, and was entitled "The publication, composition and itineraries of registration materials." During the second half of 1947, 2,404 positions were included into the CC nomenklatura and 2,171 were excluded. The inclusions happened in connection with approving positions for ministries and vedomstva and adding new ones, exclusions - in connection with decisions to slash personnel: in the local branches of the procuracy, for ex., 237 were slashed, in the Ministry of Internal Affairs -181 , in the Ministry of State Security -210 etc. 
At the same period, 2,940 people were nominated to nomenklatura positions, 2,166 were dismissed (unclear - some might have been transferred, but never to a non-nomenklatura post, unless punished). 4,090 personal files were created, 7,171 personal files were cancelled, enough to keep the staff quite busy. All in all, on July 1, 1947, the Upravlenie kept 59,516 personal files for employees on active personal rolls and 192,039 of those who were removed from personal rolls (but their files stayed). This already offers an inkling of the problem: considering that the registration of party membership in general and the special attention given to leading personnel in particular were central to the party's philosophy of ruling and monitoring leading cadres. But distribution and registration generated a great deal of fuss, a lot of pedantry and a file-keeping system of staggering dimensions. A project for a registration system - signed by the deputy-chief of the Upravlenie, Revskii, on January 21, 1948 - offered guidelines for creating "a unified system of personal-cum-position registry." In order to achieve it, a long list of various types of registration documents would be required. Party bodies would be asked to supply data on all their nominations and dismissals. It was expected they would be reluctant to tell the truth - because they used to commit quite a lot of irregularities in this domain. A description of what a "personal file" on each nomenklatura job holder would be composed of mentions inter alia personal sheets, endless cards to be filled out, and special index-cards by branch of activity.

Further details about the whole registration system would be overbearing, but it is already obvious that the effort to be invested in just the clerical aspects of handling the endless sheets, cards and files (always in need of updating), points to an air of "surrealism" that permeates the whole enterprise. It makes one think that the nomenklatura system could work only by constantly breaking at least many of its own rules. The unwieldy party-state machinery could continue to function on condition of accepting informal arrangements by all involved, and adapting to widespread behavior that made many formal procedures irrelevant. My study shows that this did in fact happen, bringing a degree of realism and a modicum of badly needed flexibility. If one thinks of the changes that happened during Khrushchev's time and later - their substance could be described by precisely this kind of formal or, more often, tacit acceptance of realities, with a considerable bending of rules or disregarding them altogether.

\section{The apparatus' salaries and the special role of benefits}

Salaries were, of course, essential but the perks, in particular, played a crucial material and symbolic role. They enabled and shaped a way of life and a certain self-image, they were a sign of recognition, if not an outright bribe, a cherished set of gratifications, psychologically more precious than the salary itself - because, simply, they made the difference. The party brass and staffs were as keen on all these "goodies" as the other apparaty and, in fact, actually initiated the whole system of perks and of the scramble for having them. 
Salaries were themselves composed of a base pay that often was wrapped up in a changing array of all kind of incentives and inducements - the higher the post the more liberal not just the salary but also those extras. We get the picture from a "Salary roll of the CC of CPSU, for 1958" 33 that details the salaries paid to each rank among the 1,118 political and 1,085 technical CC personnel - a total of 2,203 people (see Table 1).

Table 1 - Salary roll of the CC of CPSU, for 1958 (in thousands of rubles)

\begin{tabular}{|c|c|c|c|c|}
\hline position & monthly basic pay (oklad) & $\begin{array}{l}\text { monthly } \\
\text { salary } \\
\text { fund }\end{array}$ & $\begin{array}{l}\text { total } \\
\text { monthly } \\
\text { fund }\end{array}$ & $\begin{array}{l}\text { total } \\
\text { yearly } \\
\text { fund }\end{array}$ \\
\hline \multicolumn{5}{|c|}{1,118 leading (politics) personnel (rukovoditeli) - ladder of 28 positions or ranks } \\
\hline 1. & 8 Central Committee secretaries & 8 & 64 & \\
\hline \multicolumn{5}{|l|}{$\cdots$} \\
\hline$\cdots$ & $\begin{array}{l}5 \text { engineers of the Business Department } \\
\text { (Upravlenie delami) }\end{array}$ & $1,8-2,5$ & 10,4 & \\
\hline \multicolumn{5}{|l|}{$\cdots$} \\
\hline$\cdots$ & $\begin{array}{l}4 \text { managers of subsectors of the Business } \\
\text { Department }\end{array}$ & $1,8-3,0$ & 9,2 & \\
\hline \multicolumn{5}{|l|}{$\ldots$} \\
\hline \multicolumn{5}{|l|}{28} \\
\hline total & all leading personnel & & 3727,6 & 44,731 \\
\hline \multicolumn{5}{|c|}{1,085 technical CC personnel - ladder of 131 positions or ranks } \\
\hline 1. & $\begin{array}{l}\text { deputy of the Chief account } \\
\text { (in the main accounting office of the CC's } \\
\text { Business Department) }\end{array}$ & 2,1 & 2,1 & \\
\hline \multicolumn{5}{|l|}{ 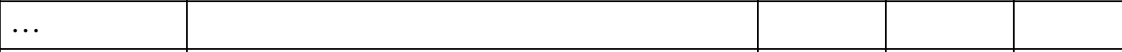 } \\
\hline$\ldots$ & 12 sector secretaries & $0,5-0,7$ & 8,4 & \\
\hline \multicolumn{5}{|l|}{$\cdots$} \\
\hline$\ldots$ & 5 telephone operators & $0,6-0,7$ & & \\
\hline total & & & 1017,8 & 12,214 \\
\hline total & 2,203 CC personnel & & 4745,4 & 56,945 \\
\hline $\begin{array}{l}\text { salary } \\
\text { supplements }\end{array}$ & $\begin{array}{l}\text { for length of service, knowledge } \\
\text { of foreign languages, two monthly salaries } \\
\text { for "rehabilitated officials" }\end{array}$ & & & 600 \\
\hline total salaries & with salary supplements & & & 57,545 \\
\hline \multicolumn{5}{|c|}{ roll of expenses for medical allowances } \\
\hline & $\begin{array}{l}\text { 1,118 "political” (otvestvennye) } \\
\text { leading personnel }\end{array}$ & & & 3,711 \\
\hline & 1,085 technical personnel & & & 695 \\
\hline total & $\begin{array}{l}\text { expenses for medical allowances } \\
(1,971 \text { officials })\end{array}$ & & & 4,271 \\
\hline
\end{tabular}

33. RGASPI, f. 17, op. 75, d. 17,1. 62-67. "Raschet po zarplate TsK KPSS na 1958 god." 
A memo entitled "Ob obsluzhivanii sotrudnikov apparata Ts. K. detskimi uchrezhdeniiami, domami otdykha i dachnymi khoziaistvami na 1945, 1946"34 and a plan for 1947 list the following services: day-care centers, nursery schools, kindergartens, summer and winter camps for children, resting houses for families for longer stays, for one-day stays. The account meticulously reported on who used all these facilities, when, for how much per day.

For each position there was a report on how many institutions, kids or employees were served, how many working days were needed, for how much per day. The actual number of such facilities and their cost was not huge, so far - but they were going to grow over the next years. In fact, the head of the medical care sector in the CC's Business Department wrote in September 194935 a projection for 1950 of travel permits for party officials requiring treatment in "special sanatoria" or sanatoria belonging to agencies other than the CC. He anticipated about 16,998 requests to 10 party-owned sanatoria (listed by name) costing 29,515, 400 and another 1,000 to sanatoria of other agencies at a cost of 1,700,000. A scribble on the document asserts that 1,200,000 will be needed for the Business Department's own collaborators.

Expenditures on local party bodies for $1945^{36}$ had a budgetary structure similar to the one of the CC. 37

What is remarkable is how well and with what meticulous care all this was documented and budgeted - and this applies to any other, administrative and political expenditures of the CC. Money and cost were counted seriously in the CC apparatus - and all the data, to the last penny, are available. We do not hear much of big money scandals or embezzlement inside the CC: the finances were a neat operation but - as everything else concerning the party - this information was top secret. The political reasons for secrecy are known to us, but we also understand that the special care lavished on the party bureaucracy (and we omitted privileged access to closed supply networks) - with such an attentive emphasis on scaling the benefits by rank - had better be kept secret. The practice and the ethos of the institution did not smack of any "communism" - but this was their business. Ours is to learn about the institution (and the system) as they were. What can be added here, in the same context, is that the steep and scrupulously "calibrated" pyramid of rank and privileges distributed in diminishing size down the ladder, was inducing those who got there, in the first place - to climb. The best position was only the one above. The power of any bureaucratic large-scale organizations to instill this kind of values is indisputable. But most of them do not pretend to harbor egalitarian ideals. Nor do they control or aim at controlling the whole political system and society. The one we study here did officially profess egalitarian ideals - but the

34. Ibid., d. 8, 1. 296.

35. Ibid., d. 9,1. 54.

36. RGASPI, f. 17, op. 75, d. 3, 1. 8.

37. Ibid. 
real thing functioned differently from what official pronouncement wanted us to believe. The conclusion will elaborate upon this last statement.

\section{Conclusion}

There is no doubt that these post-war years were endowed with many time-bound, specific features that did not apply later. But my ongoing broader study of the Soviet bureaucracy convinced me that some basic features of the party's handling of personnel in those years - in its own ranks and in government administrations at large - were there to stay. It was not just "in the past." But its efficacy was constantly declining.

The technique called "nomenklatura" was, or became, the party's main method of both supplying cadres to all the positions of importance all over the Soviet system and for making sure that they follow, broadly speaking, the party line whatever it might have been at any particular time. Cadres, as the regime discovered and preached early on, were a decisive factor and the Central Committee created a special apparatus that was to deal, in particular, with the problem of "staffing" - its own party agencies in the first place, and next - the whole sprawling state machinery.

It was hoped, officially, that having departments for cadres in all agencies (supervised by the central Party Body, whatever its current name) would provide a "weather-proof" method for producing a loyal and effective tool for executing policies as formulated at the top. Moreover, the selection and control of policy executors also proceeded from the same source - flowing from the CC down, through well maintained, faultless lines. Many were made to believe that this actually worked as intended. The impression even prevailed, and was spread by some authors that the same procedure tended to insure the entry into the apparatus of officials with particularly sought after, or encouraged, psychological and cultural features, not just ideologically loyal, but also basically subservient and conformist careerists, reflecting the preference and the mentality of those who handle the personnel lists. If those lower down in the state or party bodies had also some nominating rights, their being themselves pre-selected nomenklaturshchiki, presumably assured the continuing supply, down to the lowest rungs, of similar human specimens.

Still, on the basis of research already done, including on the nomenklatura techniques, it is possible to state that although all (or almost all) top positions were in the safe hands of party members - this did not stop one bit the development of proclivities inherent in any bureaucracy, including - of course - some features specific to each case. This is why we can say - even underline - that the Center, despite its avowed intentions, could not stop "sociology" from doing its job, neither inside bureaucracy nor in society at large. Not "even" inside the party.

The details we offered show that the staffing of the governing and administering agencies was not an operation resembling some smooth flow from the center down 
the stream. This was not even how the system functioned formally. The concentration on the "nomenklatura" of the CC level made sometimes miss the fact that important layers of officials - as we explained - were on the ministerial or other agencies' own nomenklatura - and the same applied to both party and state echelons. But even this might have created an exaggerated impression of tidiness of the whole personnel policies. In fact, only part of the positions on each level could be nominated directly - other positions required "coordination," had to be negotiated with a higher or parallel body and we already know that part of the jobs that were exclusively dependent on the approval of the $\mathrm{CC}$ was also, in fact, split into three levels, with approval rights divided between the PB, the Secretariat and the cadres' department. The opening this created for alliances and lobbying activities on the very top level can easily be perceived.

Yet, the monopoly of the final approval in the CC did mean in most cases, precisely, just "approval." Normally heads of agencies or departments were supposed "to help" the higher bodies to manage their nomenklatura. This could mean, in practice, that the minister or another boss of any level in the hierarchy, could - and was actually expected - to suggest candidates for a CC nomenklatura post. And many certainly had the means and the skills to fight for their preferred candidate.

These facts allow us to state that the whole picture was anything but orderly or tightly monolithic. The process of cadres selection was not just a decision-making "ladder," but rather a process full of loopholes and interaction, in fact, it was an enormous bargaining field, a cadres market or a transit depot - prokhodnoj $d v o r$ - as some party members bitterly protested already in the 1920s. And ministers could also apply (and lobby) to include some jobs into the $\mathrm{CC}$ nomenklatura in the first place - or else to remove jobs from this list - if they felt (or at least argued) that these jobs were too sensitive and mobile for them to be blocked by stringent $\mathrm{CC}$ regulations. That is, there was much more play, more room to jostle for power than there would have been with the stern imposition of names from above.

Moreover, if the decisions concerning the staffing were actually - and quite officially - distributed over a ladder of nomenklatura lists, the descent down the "ladder" of job decisions was strewn with interstices due to changing bargaining abilities and relations of power between the participants and to a powerful impact of "anomalies" - or "deviant" behavior. The latter consisted of widespread informal or illegal practices, triggered by devotion to institutional vested interests (frowned upon officially as manifestation of vedomstvennost'), or by recruiting practices based on group or family connections, denounced as family-spirit (semeistvennost'). Lobbying techniques were well-developed and often used to extract additional resources or cadres from the Center. Lobbying also took a variety of guises, including the fight for "slack" - a term that denotes the bureaucratic tendency the world over to accumulate more or less hidden reserves of equipment, machines, labor, money and personal helpers and deputies. "Slack" also means cultivating alliances with party and state officials indispensable to lobbying and the other tools of pressure politics. 
These facts point to the obvious: despite the intention of the nomenklatura system, the entry into the administrations, including the party's own, was only partly mastered from above. Many people got their jobs through diverse entries and channels - including independent and lateral ones. Thus the "nomenklatura," as a "ruling class" designated by uniform methods was not, in reality, that rigidly controlled by a central will, or strictly drawn from one preferred pool of candidates. The class of bosses, bigger and smaller, came "in all sizes" through different channels, contacts, pressures and other combinations of factors. In many services they also came because they were talented.

Had the method of nomenklatura selection been as simple and foolproof as the party apparatus hoped, the job of this or that cadres' department in Moscow, as well as the job of the latter-day researcher, would have been just as simple. However, despite the supposed "class solidarity" of the privileged nomenklaturshchiki, and the dependence on and devotion towards the most powerful among them which that implies, the historical record tells a different story.

But the rough-and-tumble world of Soviet bureaucracy was not responsive to any one controlling method. In addition to the powerful controlling agencies we already mentioned, a host of additional bodies was constantly needed, often carrying the designation of "special" or "extraordinary": "extraordinary" political departments (on and off), "special" or "extraordinary party organizers" to become envoys to institutions considered of critical importance, special CC bureaus for vulnerable administrative or ethnic areas, displacing in fact the regular local party bodies - most of them nomenklaturshchiki themselves.

When surveying the controlling agencies, some endowed formally with extraordinary powers, we noticed a rather astonishing fact - they did not last very long. The more powerful the controlling agency became the sooner it would be scuttled, by being actually disbanded or by being deprived of potent means of insight and intervention. The "Nomenklatura" (in the sense of the whole cohort of officials) fought back against any agency that wanted to control it too efficiently. Under Stalin the battle against manifestations of bureaucratic self-interest against its "sociology" as it were - took on pathological and deadly forms. After him, the Center still continued to fight against all kinds of bureaucratic proclivities or malpractices - sometimes by showering more privileges on this already privileged groups. But it all ended, finally, in losing control of the ship because "nomenklatura" as a nomination-dismissal power was weaker than the internal drives of a bureaucracy whose main controller resided in one party Center. Party membership could not mean much per se inside a bureaucracy where everybody who was anybody was a member and on some nomenklatura or other. His career, well-being and importance finally depended on bureau-ministerial interests. Appropriately enough, people from their milieu could also be found, seated high in the same Center, i.e. in the $\mathrm{CC}$ or on influential policy-making. Commissions that were often constituted to solve an urgent problem or respond to some crisis or other were also staffed by the same, as Russians called them, sanovniki (the regime's grandees). 
The widespread idea that this huge machinery was picking types of persons responding to a preferred blueprint, invariably fanatical, invariably monolithic ideologically, predictably mediocre and dumb, necessarily also always self seeking - cannot be accepted. Such effects and results actually materialized to some extent. On the other hand we still know these apparaty very little. In order, for instance, to ascertain the psychological, ethical or ideological make of the party or state cadres, preconceived ideas or limited personal observations are no guide. There are many administrations on earth that easily lean towards, say, authoritarian personalities, discourage brilliance or talent, and promote in-house loyalty and conformism. In Russia, I personally observed some high-level bosses, in the army and elsewhere, notably on the lower rungs of different agencies. The conclusion that I was facing obvious "blockheads" came easily and justifiably to mind. But jumping to conclusions from such impressions would mean just that: "jumping." Much more sociological, cultural and personal variety and even ideological diversity existed and could be observed, and the abundance of operators ready for and skillful in informal - even quite deviant - lobbying make the exaggeration of the nomenklatura's potency rather misleading. We are still far from being able to assess Soviet bureaucracies, at different times, from the point of view of their abilities, skills and mentalities. And many less subtle tasks have to be tackled first in researching the Soviet state apparatus.

Handling all the top cadres of the whole party and state personnel by a department in the $\mathrm{CC}$ was not a very realistic proposition in the first place, except, no doubt, at the launching of a new political "offensive." The ever more intricate personnel problems in an ever more complex state machinery kept literally blowing up the Center's administrative structures, forced it to try centralization, then to turn to decentralization, back to recentralization again, almost cyclically. Ideally the Center would like its operations to run smoothly and efficiently - and prove it by avoiding unwieldy structures in its own apparatus. After all, unwieldy and inefficient structures were the very thing the party apparatus tried to combat. In fact, they managed to keep the numbers of the party's own paid officialdom quite steady, as 1946-1948 and later-date figures prove. But the efficiency of this top controller was another matter.

The heads of the bureaucracy - some of them Politbiuro members themselves and the party's apparatus (with their whole nomenklatura paraphernalia) were trying to handle a complicated maze. This is why the nomenklatura was not just controlling - it was also "huffing and puffing."

Consequently, more was going on than just fixing lists and running the show according to lists and apparatus - like instructions and orders. The supposed magic ability of the party to afford a tailor cut bureaucratic machinery made to order is just a legend. It is true that people of the nomenklatura list were - as an agglomerate - the rulers of all levels of the hierarchy. Precisely so and it meant, as said, a power game - lobbying, intriguing, bribing, yielding etc., amounting in actual fact to some kind of power sharing already in Stalin's time, and a fullness of power for the bureaucracy after Stalin. Such a powerful position for the 
bureaucracy was new to Russia's history. And new even to the Soviet system itself - and it had to end in a rewriting of the relations between state and party bureaucracies. The potency of "nomenklatura"-based techniques of control of the latter over the former was fading very fast, partly during the 1960s and especially during the years called "zastoi" that coincided with the rule of Brezhnev as "gensek."

The whole complex of cadres' policy had a feedback effect on and against the party leadership. The meetings of all the ruling bodies - Secretariat, Orgbiuro, Politbiuro - were clogged with "personalia" (personal'nye voprosy) and other practical details that left little time, energy or even competence for serious policymaking. The system in those years functioned, paradoxically, sometimes better, sometimes worse, only because spontaneous forces at work - I call it "sociology" caused a loosening of the nomenklatura grip (and of the concurrent need to create more controlling apparaty). The aging regime had no choice but to adapt itself to the unavoidable. A "radical" response resembling Stalinist purges was not available anymore. Purges were actually helpless even then. It allows us to speak metaphorically of the backlash or revenge of the bureaucratic giant against the smaller bureaucratic controller that kept drowning in its paper-flood and the minutiae engendered by an obsolete way of conducting the affairs of a modern state.

The documents reflecting the situation after the war show quite convincingly one of the key factors that made the political agency - namely the party - falter and lose its political effectiveness. Engaging itself directly in running the economy of the country that required the inefficient nomenklatura procedures, could not prevent a much stronger process: the administrative agencies directly responsible for executing the relevant jobs "economized" the party through this "backdoor," transformed it into yet another administration and opened the door to its assimilation by the larger administrative machine. It is interesting that a party secretary like A. A. Kuznetsov, supposedly quoting Stalin, characterized this phenomenon as "being bribed" by the economic agencies or even by a more telling diagnosis: the party apparatus became "an appendix" to the managers of the economy (which certainly included the armament industries). At that time such phenomena could still be at least partly explained away by the wartime or post-war conditions, and hence amenable to being reversed. But the process of getting enmeshed with ministerial apparaty was not stoppable. The only chance for the so called "party" to be obeyed, or look like being obeyed, consisted in accepting the inevitable - becoming an appendix to and part of the upper layers of the governmental machinery. "Till death do us part."

Exploring the vagaries of the nomenklatura procedures shows a political administration - itself a bureaucracy - at the helm of a multi-million membership that had nothing to do with political decision-making. Even this "political administration" lost its power under Stalin, regained some of it under Khrushchev, but finally yielded not to any leader but to a process (of bureaucratization) that put an end to the fiction called "The Communist Party of the Soviet Union." The party's "depolitization" - in the sense of losing the ability to formulate policies, to offer 
capable leaders, to conceive of and impose reforms (or any serious policy, for that matter) to match the depth of the sea changes that took place in the country and in the world. But the bureaucracy continued its sway unabatedly - the historical paradoxes at work here were astounding: the economic situation kept worsening but the ruling bureaucracy was thriving. Political interference and leadership were urgently needed to save the country from a collapse, but the "logic" of the administrative Dibbuk on the loose undermined the political agency (or whatever still survived of it) and made redundant the small wheel that was trying to give orders to the big one. The final irony, quite pertinent to Russia's post-Soviet situation, resides in the fact that although "the party-state" has gone - the ministries have stayed on.

University of Pennsylvania

Department of History

208 College Hall

Philadelphia PA 19104 